This article is licensed under the Creative Commons Attribution-NonCommercial 4.0 International License (CC BY-NC) (http://www.karger.com/Services/OpenAccessLicense). Usage and distribution for commercial purposes requires written permission.

\title{
A Small Bowel Ulcer due to Clopidogrel with Cytomegalovirus Enteritis Diagnosed by Capsule and Double-Balloon Endoscopy
}

\author{
Masahide Ebi Satoshi Inoue Tomoya Sugiyama Kazuhiro Yamamoto \\ Kazunori Adachi Takashi Yoshimine Yoshiharu Yamaguchi \\ Yasuhiro Tamura Shinya Izawa Yasutaka Hijikata Yasushi Funaki \\ Naotaka Ogasawara Makoto Sasaki Kunio Kasugai \\ Department of Gastroenterology, Aichi Medical University School of Medicine, \\ Nagakute, Japan
}

\section{Keywords}

Clopidogrel · Cytomegalovirus $\cdot$ Small bowel ulcer

\section{Abstract}

We report the first case of small bowel ulcers due to clopidogrel in a 74-year-old man. He presented with diarrhea and melena after having been taking low-dose aspirin (LDA) and clopidogrel. There was no evidence of bleeding in the stomach, duodenum, or colon. Capsule endoscopy showed multiple ulcers and erosions in the small intestine. Double-balloon endoscopy revealed multiple ulcers throughout the ileum. Examination of the biopsy specimen showed cytomegalovirus infection. His LDA was discontinued and he was prescribed ganciclovir. However, the small bowel ulcers were aggravated. Therefore, clopidogrel was discontinued. The small bowel ulcers subsequently healed completely, forming scars.

(C) 2018 The Author(s)

Published by S. Karger AG, Basel 


\section{Case Reports in Gastroenterology}

Case Rep Gastroenterol 2018;12:303-310

DOI: 10.1159/000490096

(c) 2018 The Author(s). Published by S. Karger AG, Basel www.karger.com/crg

Ebi et al.: A Small Bowel Ulcer due to Clopidogrel with Cytomegalovirus Enteritis

Diagnosed by Capsule and Double-Balloon Endoscopy

\section{Introduction}

Small bowel ulcers occur due to Crohn's disease, Behçet's disease, cytomegalovirus, tuberculosis, bacterial overgrowth, chronic pseudoileus, small intestine diverticula, vasculitis, Churg-Strauss syndrome, ischemic ileitis, or drug induction, and maybe simple ulcers. Lowdose aspirin (LDA) has been reported to cause small intestinal injury and 57.6\% of chronic users had mucosal breaks. Clopidogrel is a platelet aggregation inhibitor used for the treatment of acute coronary syndrome and chronic vascular stenosis. While dual antiplatelet therapy decreases cardiovascular events after successful coronary drug-eluting stenting, it is considered to increase the risk of gastrointestinal bleeding [1]. There are no previous reports of small bowel injury due to clopidogrel.

\section{Case Report}

A 74-year-old man visited our hospital due to diarrhea and melena which had persisted for 4 months. He had undergone left lobectomy with lymph node dissection and received adjuvant chemotherapy for lung cancer 6 months earlier. He experienced an ischemic heart event 3 months before presenting to our hospital and had been taking LDA and clopidogrel ever since. His physical examination revealed anemia in his conjunctiva and skin but no abdominal symptoms. The laboratory data revealed severe anemia but no other abnormalities (Table 1). An upper gastrointestinal endoscopy revealed angioectasia in the stomach. However, there was no blood found in the stomach or duodenum. A colonoscopy found no polyps, tumors, or bleeding lesions. Capsule endoscopy (CE) revealed multiple ulcers and erosions in the small intestine (Fig. 1a, b). We performed transanal double-balloon endoscopy (DBE), which showed multiple ulcers throughout the ileum with severe ulceration in the terminal ileum (Fig. 2a, b). Biopsy specimens were obtained from the ulceration. We diagnosed the patient with non-steroidal anti-inflammatory drug-induced ulceration caused by LDA according to the endoscopic findings. Histological examination revealed cytomegalovirus (CMV) infection in the ileum. To treat the ulcers, he was prescribed misoprostol and continued the LDA. However, 7 days later, he had repeated melena and dizziness due to anemia. We performed DBE again and found that the multiple ulcers in the ileum were obviously exacerbated (Fig. $3 \mathrm{a}, \mathrm{b})$. We considered this to indicate that the small intestine ulcers were caused by the CMV and the patient was administered ganciclovir $(5 \mathrm{mg} / \mathrm{kg}$ ) for 10 weeks. DBE was performed again 5 weeks after the previous DBE and found that the ulcers had decreased in size, but had not healed. There was no evidence of CMV infection during the histological examination. Therefore, the ulcers were considered to have been due to clopidogrel, which was discontinued. The patient had no subsequent episodes of melena or abdominal symptoms. DBE performed 8 weeks later showed that the small intestine ulcers had completely healed and turned into scars (Fig. 4). 


\section{Case Reports in Gastroenterology}

Case Rep Gastroenterol 2018;12:303-310

DOI: $10.1159 / 000490096$

(c) 2018 The Author(s). Published by S. Karger AG, Base www.karger.com/crg

Ebi et al.: A Small Bowel Ulcer due to Clopidogrel with Cytomegalovirus Enteritis

Diagnosed by Capsule and Double-Balloon Endoscopy

\section{Discussion}

This is the first report of multiple ulcers in the small intestine due to clopidogrel. Clopidogrel, an adenosine diphosphate (ADP) receptor antagonist, inhibits platelet aggregation by irreversibly inhibiting ADP-induced activation of platelet fibrinogen (glycoprotein IIb/IIIa) [2]. Clopidogrel has been used for atherosclerotic disease [3]. It prevents thrombotic events in patients with stable cardiovascular disease and is useful for secondary prevention after myocardial infarction and stroke [4].

We initially diagnosed the small bowel ulcers to be caused by LDA because the patient had been taking both LDA and clopidogrel, and several previous reports had found small bowel injuries caused by LDA administration [5-8]. On the other hand, Tsai et al. [9] reported that the upper gastrointestinal lesions in patients taking clopidogrel were mainly hemorrhage spots and peptic ulcers, and were more frequently observed than in patients taking aspirin.

Various features of gastrointestinal lesions due to LDA have been described such as multiple petechiae, loss of villi, erosions, and round, irregular, and punched-out ulcers [10]. In fact, it is difficult to diagnose the cause of small bowel injuries. Iwamoto et al. [7] reported that $64.3 \%$ of patients taking LDA had ulcerative or erosive lesions in their small intestines. Shiotani et al. [11] described that concomitant use of thienopyridines, such as clopidogrel, with LDA increased the incidence of ulcers in the small intestine.

Our patient had been taking both LDA and clopidogrel and the ulcers did not resolve after he discontinued LDA. It has been hypothesized that ADP receptor antagonists may cause gastrointestinal injury through an impairment of ulcer healing [12]. Moreover, clopidogrel attenuation of the angiogenesis needed for gastric ulcer healing by the inhibition of the VEGFVEGFR-2-ERK signal transduction pathway has been reported [13].

CMV infection occurs in patients with immune deficiency, such as those receiving chemotherapy for malignancies or steroid therapy, and those with acquired immunodeficiency syndrome [14]. Our patient had undergone surgery for lung cancer and received adjuvant chemotherapy after the operation. The gastrointestinal lesions due to CMV infection have been reported to be of a geographic or punched-out shape with a variable depth [15]. In our case, geographic-shaped ulcers were seen in the small intestine. The ulcers were considered to be caused by CMV infection and the patient received anti-CMV treatment. However, the ulcers did not improve, although there was no evidence of CMV infection on the post-treatment histological examination of the biopsy specimen. Subsequent discontinuation of clopidogrel led to a pronounced improvement of the lesions as confirmed by DBE 2 months later.

CE is a minimally invasive tool for the investigation of small intestines $[16,17]$. It has been shown to be useful for the diagnosis and follow-up of Crohn's disease [18-20] and LDAinduced small bowel mucosal injuries [21]. Meanwhile, DBE can examine the entire intestine [22]. DBE can obtain a specimen for histological diagnosis and treat small intestine diseases [23-25]. Concomitant CE and DBE may enable the diagnosis of small intestine diseases $[26,27]$.

In conclusion, we reported the first case of small intestine ulcers due to clopidogrel. There should be more careful monitoring of gastrointestinal bleedings in patients on clopidogrel. 


\section{Case Reports in \\ Gastroenterology}

Case Rep Gastroenterol 2018;12:303-310

(C) 2018 The Author(s). Published by S. Karger AG, Base www.karger.com/crg

Ebi et al.: A Small Bowel Ulcer due to Clopidogrel with Cytomegalovirus Enteritis

Diagnosed by Capsule and Double-Balloon Endoscopy

\section{Statement of Ethics}

The authors have no ethical conflicts to disclose. Informed consent was obtained from the patient.

\section{Disclosure Statement}

K. Kasugai received research grants and lectures fees from AstraZenekca K.K., Daiichi Sankyo Co., Ltd., and Takeda Pharmaceutical Co., Ltd.

\section{References}

1 Guo Y, Wei J. Clinical outcomes of various continued antiplatelet therapies in patients who were administered DAPT following the implantation of drug-eluting stents and developed gastrointestinal hemorrhage. Exp Ther Med. 2016 Aug;12(2):1125-9.

2 McQuaid KR, Laine L. Systematic review and meta-analysis of adverse events of low-dose aspirin and clopidogrel in randomized controlled trials. Am J Med. 2006 Aug;119(8):624-38.

3 Terpening C. Clopidogrel: a pharmacogenomic perspective on its use in coronary artery disease. Clin Med Insights Cardiol. 2010 Dec;4:117-28.

4 Jackowski L, Stocks N, Rowett D. Reducing the risk of adverse thrombotic events - The role of aspirin and clopidogrel. Aust Fam Physician. 2008 Sep;37(9):721-3, 725-6.

5 Endo H, Hosono K, Inamori M, Nozaki Y, Yoneda K, Fujita K, et al. Characteristics of small bowel injury in symptomatic chronic low-dose aspirin users: the experience of two medical centers in capsule endoscopy. J Gastroenterol. 2009;44(6):544-9.

6 Ehrhard F, Nazeyrollas P, Brixi H, Heurgue-Berlot A, Thiéfin G. Proximal predominance of small bowel injury associated with uncoated low-dose aspirin therapy: a video capsule study in chronic users. Eur J Gastroenterol Hepatol. 2013 Nov;25(11):1265-72.

7 Iwamoto J, Mizokami Y, Saito Y, Shimokobe K, Honda A, Ikegami T, et al. Small-bowel mucosal injuries in low-dose aspirin users with obscure gastrointestinal bleeding. World J Gastroenterol. 2014 Sep;20(36):13133-8.

8 Chen WC, Lin KH, Huang YT, Tsai TJ, Sun WC, Chuah SK, et al. The risk of lower gastrointestinal bleeding in low-dose aspirin users. Aliment Pharmacol Ther. 2017 Jun;45(12):1542-50.

9 Tsai TJ, Lai KH, Hsu PI, Lin CK, Chan HH, Yu HC, et al. Upper gastrointestinal lesions in patients receiving clopidogrel anti-platelet therapy. J Formos Med Assoc. 2012 Dec;111(12):705-10.

10 Endo H, Sakai E, Kato T, Umezawa S, Higurashi T, Ohkubo H, et al. Small bowel injury in low-dose aspirin users. J Gastroenterol. 2015 Apr;50(4):378-86.

11 Shiotani A, Honda K, Murao T, Ishii M, Fujita M, Matsumoto H, et al. Combination of low-dose aspirin and thienopyridine exacerbates small bowel injury. Scand J Gastroenterol. 2011 Mar;46(3):281-6.

12 Cryer B. Management of patients with high gastrointestinal risk on antiplatelet therapy. Gastroenterol Clin North Am. 2009 Jun;38(2):289-303.

13 Luo JC, Peng YL, Chen TS, Huo TI, Hou MC, Huang HC, et al. Clopidogrel inhibits angiogenesis of gastric ulcer healing via downregulation of vascular endothelial growth factor receptor 2. J Formos Med Assoc. 2016 Sep;115(9):764-72.

14 Rafailidis PI, Mourtzoukou EG, Varbobitis IC, Falagas ME. Severe cytomegalovirus infection in apparently immunocompetent patients: a systematic review. Virol J. 2008 Mar;5(1):47.

15 Chae EY, Lee SS, Chung JW, Kim HJ, Park SH, Kim AY, et al. Cytomegalovirus enterocolitis in apparently immunocompetent hosts: evaluation of the radiologic findings and clinical features. J Comput Assist Tomogr. 2010 Nov-Dec;34(6):892-8.

16 Wang A, Banerjee S, Barth BA, Bhat YM, Chauhan S, Gottlieb KT, et al; ASGE Technology Committee. Wireless capsule endoscopy. Gastrointest Endosc. 2013 Dec;78(6):805-15. 


\section{Case Reports in Gastroenterology}

Case Rep Gastroenterol 2018;12:303-310

Ebi et al.: A Small Bowel Ulcer due to Clopidogrel with Cytomegalovirus Enteritis

Diagnosed by Capsule and Double-Balloon Endoscopy

17 Pennazio M, Spada C, Eliakim R, Keuchel M, May A, Mulder CJ, et al. Small-bowel capsule endoscopy and device-assisted enteroscopy for diagnosis and treatment of small-bowel disorders: European Society of Gastrointestinal Endoscopy (ESGE) Clinical Guideline. Endoscopy. 2015 Apr;47(4):352-76.

18 Yang DH, Keum B, Jeen YT. Capsule endoscopy for Crohn's disease: current status of diagnosis and management. Gastroenterol Res Pract. 2016;2016:8236367.

19 Jensen MD, Brodersen JB, Kjeldsen J. Capsule endoscopy for the diagnosis and follow up of Crohn's disease: a comprehensive review of current status. Ann Gastroenterol. 2017;30(2):168-78.

20 Choi M, Lim S, Choi MG, Shim KN, Lee SH. Effectiveness of capsule endoscopy compared with other diagnostic modalities in patients with small bowel Crohn's disease: a meta-analysis. Gut Liver. 2017 Jan;11(1):62-72.

21 Watari I, Oka S, Tanaka S, Aoyama T, Imagawa H, Shishido T, et al. Effectiveness of polaprezinc for low-dose aspirin-induced small-bowel mucosal injuries as evaluated by capsule endoscopy: a pilot randomized controlled study. BMC Gastroenterol. 2013 Jul;13(1):108.

22 Yamamoto H, Sekine Y, Sato Y, Higashizawa T, Miyata T, Iino S, et al. Total enteroscopy with a nonsurgical steerable double-balloon method. Gastrointest Endosc. 2001 Feb;53(2):216-20.

23 Yamamoto H, Yano T, Kita H, Sunada K, Ido K, Sugano K. New system of double-balloon enteroscopy for diagnosis and treatment of small intestinal disorders. Gastroenterology. 2003 Nov;125(5):1556.

24 Miyata T, Yamamoto H, Kita H, Yano T, Sunada K, Sekine Y, et al. A case of inflammatory fibroid polyp causing small-bowel intussusception in which retrograde double-balloon enteroscopy was useful for the preoperative diagnosis. Endoscopy. 2004 Apr;36(4):344-7.

25 Yamamoto H, Kita H, Sunada K, Hayashi Y, Sato H, Yano T, et al. Clinical outcomes of double-balloon endoscopy for the diagnosis and treatment of small-intestinal diseases. Clin Gastroenterol Hepatol. 2004 Nov;2(11):1010-6.

26 Kita H, Yamamoto H, Nakamura T, Shirakawa K, Terano A, Sugano K. Bleeding polyp in the mid small intestine identified by capsule endoscopy and treated by double-balloon endoscopy. Gastrointest Endosc. 2005 Apr;61(4):628-9.

27 Goto H. Diagnosis and treatment of small bowel diseases are advanced by capsule endoscopy and doubleballoon enteroscopy. Clin J Gastroenterol. 2010 0ct;3(5):219-25.
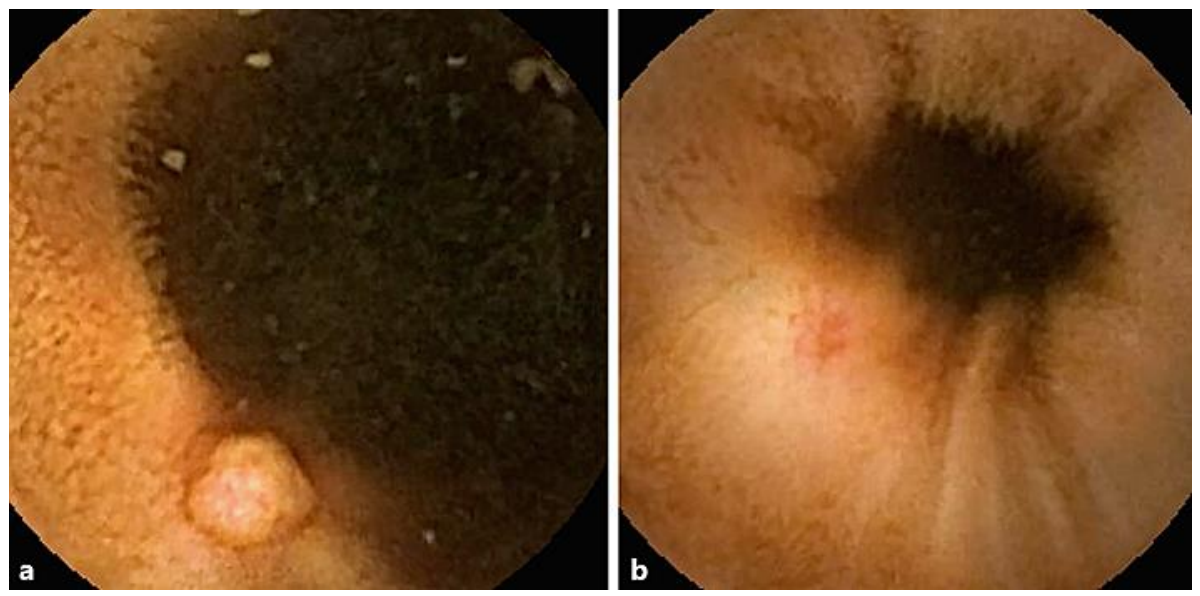

Fig. 1. Capsule endoscopy showed an ulcer (a) and an erosion (b) in the small intestine. 


\section{Case Reports in Gastroenterology}

\begin{tabular}{l|l}
\hline Case Rep Gastroenterol 2018;12:303-310 \\
\hline DOI: 10.1159/000490096 & $\begin{array}{l}\text { (c) 2018 The Author(s). Published by S. Karger AG, Basel } \\
\text { www.karger.com/crg }\end{array}$ \\
\hline
\end{tabular}

Ebi et al.: A Small Bowel Ulcer due to Clopidogrel with Cytomegalovirus Enteritis

Diagnosed by Capsule and Double-Balloon Endoscopy
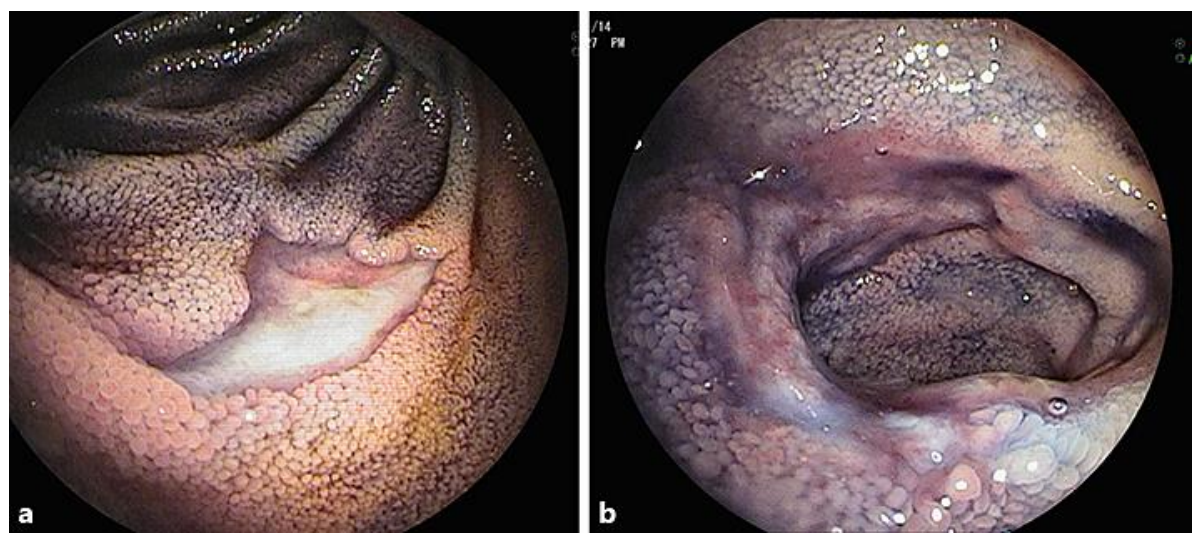

Fig. 2. Double-balloon endoscopy showed multiple ulcers throughout the ileum (a) and a severe ulcer in the terminal ileum (b).
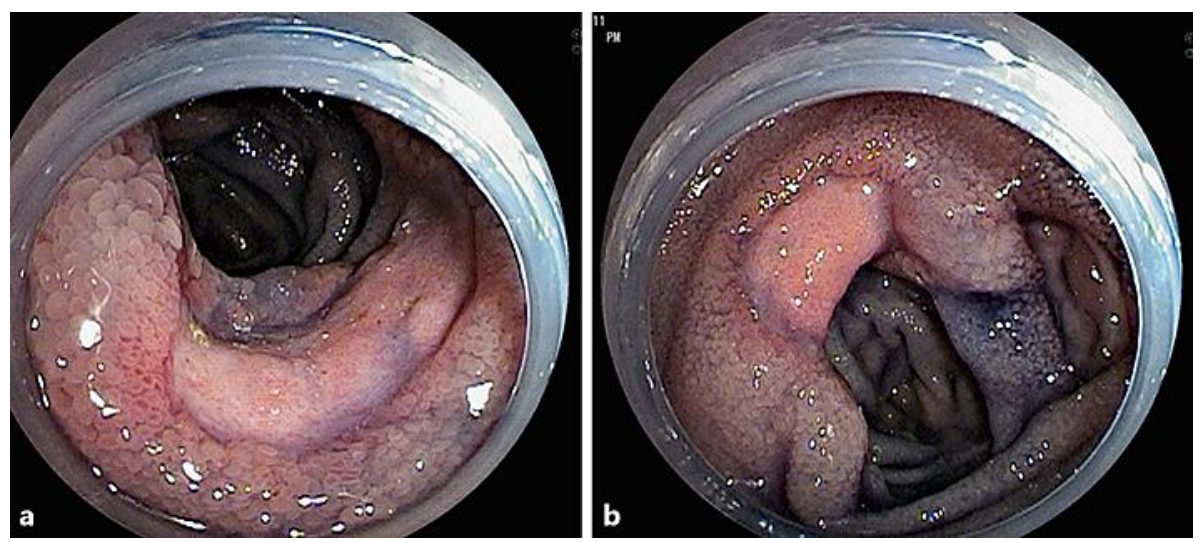

Fig. 3. Double-balloon endoscopy after discontinuing low-dose aspirin showed that the multiple ulcers in the ileum $(\mathbf{a}, \mathbf{b})$ were obviously exacerbated since the former examination. 


\section{Case Reports in Gastroenterology}

(C) 2018 The Author(s). Published by S. Karger AG, Basel DOI: $10.1159 / 000490096$ www.karger.com/crg

Ebi et al.: A Small Bowel Ulcer due to Clopidogrel with Cytomegalovirus Enteritis

Diagnosed by Capsule and Double-Balloon Endoscopy

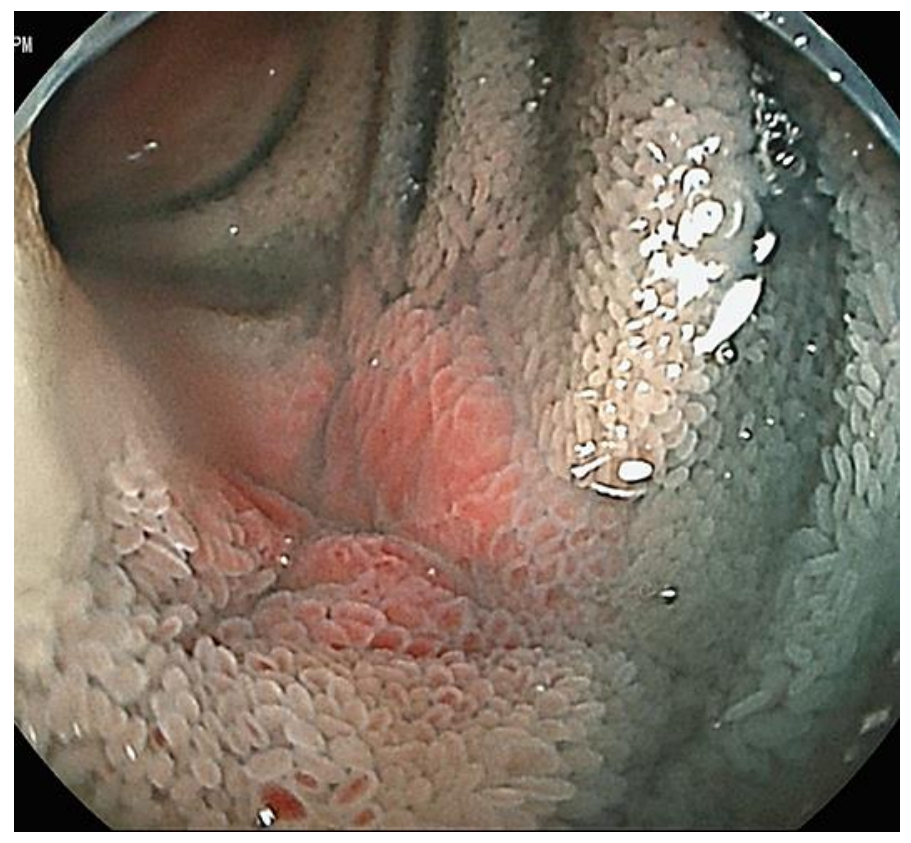

Fig. 4. Double-balloon endoscopy after discontinuing clopidogrel showed that the small intestine ulcers healed and completely turned into scars. 
Ebi et al.: A Small Bowel Ulcer due to Clopidogrel with Cytomegalovirus Enteritis

Diagnosed by Capsule and Double-Balloon Endoscopy

Table 1. Laboratory examination results on admission

Urinalysis
pH 6.5
Protein $(-)$
Glucose $(-)$
O.B. $(-)$
Urobilinogen $( \pm)$
Bilirubin $(-)$
Ketone body $(-)$

Complete blood count

WBC $6,600 / \mu \mathrm{L}$

Neu $66 \%$

Lymph 21\%

Eos $0 \%$

RBC $268 \times 104 / \mu \mathrm{L}$

$\mathrm{Hb} 8.0 \mathrm{~g} / \mathrm{dL}$

HT $24.9 \%$

Plt $6.8 \times 104 / \mu \mathrm{L}$

\author{
Biochemistry \\ TP $6.1 \mathrm{~g} / \mathrm{dL}$ \\ Alb $3.6 \mathrm{~g} / \mathrm{dL}$ \\ T-bil $0.43 \mathrm{mg} / \mathrm{dL}$ \\ AST $20 \mathrm{U} / \mathrm{L}$ \\ ALT $16 \mathrm{U} / \mathrm{L}$ \\ LD $138 \mathrm{U} / \mathrm{L}$ \\ $\gamma$-GTP $28 \mathrm{U} / \mathrm{L}$ \\ CK $34 \mathrm{U} / \mathrm{L}$
}

BUN $22.6 \mathrm{mg} / \mathrm{dL}$

Cr $0.74 \mathrm{mg} / \mathrm{dL}$

$\mathrm{Na} 142 \mathrm{mmol} / \mathrm{L}$

$\mathrm{K} 4.1 \mathrm{mmol} / \mathrm{L}$

Cl $110 \mathrm{mmol} / \mathrm{L}$

CRP 0.18

Immunology

HBs-Ag $0.02 \mathrm{IU} / \mathrm{mL}$

HBs-Ab $0.2 \mathrm{mIU} / \mathrm{mL}$

$\mathrm{HBc}-\mathrm{Ab} 0.09 \mathrm{~S} / \mathrm{CO}$

$\mathrm{HCV}-\mathrm{Ab}<0.10 \mathrm{~S} / \mathrm{CO}$

HCV-Ag <3.0 fmol/L

HIV-1/2-Ab (-)

CMV-Ag (C7-HRP) (-)

O.B., occult blood; WBC, white blood cell count; Neu, neutrophil; lymph, lymphocyte; Eos, eosinophil; RBC, red blood cell count; $\mathrm{Hb}$, hemoglobin; HT, hematocrit; Plt, platelet; TP, total protein; Alb, albumin; T-bil, total bilirubin; AST, aspartate aminotransferase; ALT, alanine aminotransferase; LD, lactate dehydrogenase; $\gamma$-GTP, gammaglutamyl transpeptidase; $\mathrm{CK}$, creatinine kinase; Na, sodium; $\mathrm{K}$, potassium; Cl, chloride; CRP, C-reactive protein; HBs-Ag, hepatitis B surface-antigen; HBs-Ab, hepatitis B surface antibody; $\mathrm{HBc}-\mathrm{Ab}$, hepatitis B core antibody; HCV-Ab, hepatitis $\mathrm{C}$ virus antibody; HCV-Ag, hepatitis $\mathrm{C}$ virus antigen; HIV-1/2-Ab, human immunodeficiency virus $1 / 2$ antibody; CMV-Ag(C7-HRP), cytomegalovirus antigenemia. 